\title{
Modified Cassava Flour Dates Biscuit Effect on the Lipid and Anthropometry Profiles of Type 2 Diabetes
}

\author{
Fatmah* $^{*}$ \\ Public Health Nutrition Dept., Faculty of Public Health, Universitas Indonesia, Indonesia \\ Corresponding Authors’Email: *ffatmah@yahoo.com
}

\begin{abstract}
Purpose: To assess the effect of caromma biscuit consumption on the lipid profile and anthropometry of type $2 \mathrm{DM}$ write our first time patients.
\end{abstract}

Design: A pretest-post-test randomized controlled trial (RCT) design was used on 33 subjects of an intervention group given caromma biscuits and 31 subjects of a control group given tempeh dates biscuits (temma) for four weeks. Anthropometry profile data collection included weight, height, waist-hip circumference ratio (WHCR), body fat percentage (BFP), blood pressure, and fasting blood glucose (FBG). Lipid profile included total cholesterol, Low Density Lipoprotein (LDL), High Density Lipoprotein (HDL), and triglycerides collected before and after study.

Findings: The majority of subjects in both groups had over-nutrition, high body fat percentage, risk of central obesity from WHCR, pre-hypertension, and high fasting blood glucose. Lipid profile showed high cholesterol, LDL, and triglycerides, and low HDL. At the end of the study, there was an increase of weight, BMI (Body Mass Index), BFP, and WHCR in both groups. Blood pressure, FBG, cholesterol, LDL, HDL, and triglycerides decreased in both groups.

Practical implication: Lipid and animal protein intakes should be limited for type 2 diabetic patients. It can prevent high levels of lipid profile which is danger for them. Caromma and temma biscuits can be consumed by diabetic patients to obtain a positive blood lipid profile, but not for a improve anthropometric profile.

Keywords: Type 2 DM, caromma biscuit, temma biscuit, anthropometry profile, lipid profile

\section{Introduction}

Obesity, smoking, a lack of fruit and vegetable consumption, the consumption of too much sweet food, and a lack of physical activity, such as exercise, are the risk factors of Diabetes Mellitus (DM) (Basic Health Research, 2018). DM is often asymptomatic; thus, for a long time, the patients may have no idea that they have DM. When DM is finally diagnosed, some patients' blood glucose level have elevated without their realization. Changes in lifestyle including eating habits and physical activity are preventive measures for type 2 DM. This type of DM occurs mostly in developing countries in patients aged over 45 years without insulin dependency (Samuel D, 2006).

The appropriate diet of a DM patient includes the regulation of calories, carbohydrates, fat, and protein contained in the seven groups of food classification. One way to regulate food or diet is by choosing the amount and type of appropriate carbohydrates using the concept of the Glycemic Index (GI). Foods containing high GI increase blood glucose level quickly after the food has been 
consumed. Foods high in gluten, such as flour, need to be avoided by diabetics because they can increase blood glucose level. Foods high in gluten can hinder metabolism in the form of nutritional absorption disorder in patients with type 1 and 2 diabetes, which leads to malnutrition in patients with DM (Sinta, 2013).

Various complications to other parts of the body, starting from blood vessels (atherosclerosis) to the heart (Coronary Artery Disease/CAD) can be initiated by DM. This is caused by hyperlipidemia in DM patients. Studies performed on type 2 DM patients in India proved triacylglycerol (TAG), VLDL, and cholesterol/HDL increased significantly (Jain H et al. 2016). The common nutritional status profile found in type $2 \mathrm{DM}$ patients includes over-nutrition to obesity, WHCR over the cut-off point 0.8 for women and 0.9 for men, high body fat percentage (BFP), and hypertension. Most common characteristics found in type $2 \mathrm{DM}$ include dyslipidemia, obesity, and hypertension. Dyslipidemia, commonly found in DM is insulin deficiency and resistance, which affects enzymes and the lipid metabolism pathway (Hirano, 2018). Dyslipidemia in type 2 DM patients is characterized by increased triglycerides, decreased HDL, and increased LDL (Chang YC et al. 2013).

Body fat percentage (BFP) and body mass index (BMI) have a significant correlation in DM patients. The majority of DM patients experience lipid disorder, i.e., dyslipidemia which is characterized by increased triglycerides, decreased HDL, and increased LDL. This abnormality can lead to CAD write out first time which aggravates the health status of DM patients (Kelley D.E., 2003). Management of type $2 \mathrm{DM}$ consists of pharmacological and non-pharmacological therapy to maintain the blood glucose level at a normal value. One of the non-pharmacological efforts is the consumption of food with low glycemic index (GI) to manage normal BGL. Functional food consumption may improve this condition.

A pilot study regarding the effect of the caromma biscuit on BGL changes in 141 diabetics patients. The study showed an increase of BGL at postprandial two hours after consuming the biscuit (6.4 points) was the lowest in the intervention group (caromma biscuit) compared to control group (temma, mocaf tempe kurma, and dates biscuits) (Fatmah, 2017). However, the effect on the changes of the anthropometry profile and the lipid profile in DM patients has not yet been studied. This study aimed to assess the impact of caromma biscuit consumption on anthropometry profile (BMI, WHCR, BFP) and blood lipid profile (total cholesterol, LDL, HDL, and TAG).

\section{Materials and Methods}

\section{Population and subject}

The study used a quasi-experimental design on 66 type 2 DM patients in Depok City. Ethical clearance was obtained from the Research Ethics Committee of Health Research and Development Board of the Indonesian Ministry of Health. The research design was a single-blind randomized treatment-control experimental trial with 66 subjects. From the chosen DM patients, randomization was conducted to divide the subjects into two groups. The researcher knew the type of biscuit given to the intervention and the control group (Sastroasmoro and Sofyan Ismail, 2014).

Subjects were chosen when they met the inclusion criteria as follows: male or female; aged between 35-75 years; had DM for at least 12 months; currently consuming oral diabetic medication; currently 
not drinking herbal medicine such as sour soup leaves, god's crown leaves, rosella tea, and other food that might decrease blood glucose; not currently suffering with a chronic disease such as cancer, CAD, stroke; diagnosed with type 2 diabetes mellitus by a doctor (based on fasting blood glucose level examination with the result of $>200 \mathrm{mg} / \mathrm{dl}$ and 2 hours after eating if $>126 \mathrm{mg} / \mathrm{dl}$ ) (ADA, 2010); and have symptoms of DM, i.e. polyphagia, polydipsia, and polyuria, and rapid weight loss. A power analysis showed that 30 subjects were needed in this study to observe a difference in means of at least between the two groups. There was a total of 70 subjects for the treatment group and the control group after adding 5 subjects for each group.

\section{Data collection and analysis}

Sixty-four subjects divided evenly between two groups participated in this study. The treatment group was given a caromma biscuit, and the control group was given a temma biscuit, one package per day for four weeks. The compliance level of biscuit consumption was determined by a home visit every two days to record daily food consumption and the amount of biscuit distributed. In addition, the anthropometry profiles (BMI, FBG, blood pressure, BFP, waist-hip circumference ratio) and lipid profile (cholesterol, LDL, HDL, and triglycerides) were measured before and after the study. Baseline data was collected at the start of the study which included the characteristics of the subjects, history of DM, the health status of the subjects two weeks before the interview, and one-day food recall. Their body weight was analyzed using the 2007 World Health Organization standard with WHO Anthroplus software version 02, 2009 according to body weight/age indicator. Univariate data analysis was performed using SPSS program version 13.

\section{Results}

At the beginning of the study, there were 70 subjects evenly divided between two groups (each consisting of 35 people). However, 6 subjects dropped out, either through their own resignation or being asked to leave by the author. The reasons for leaving were: the subject felt bored and decided not to continue with the study ( 2 subjects), they went home without the assurance of returning (1 subject), they were admitted to the hospital for a few days (1 subject). Thus, biscuit consumption was stopped, or they complained of frequent urinating after biscuit consumption ( 2 subjects). The majority were females less than 60 years of age. The mean subject age was considered homogenous between the two groups from 50 years to 60 years. Subjects in the intervention and control group had mostly finished their education at a low level (nine years of education). More than three-quarters of the total subjects in both groups were unemployed (Table 1).

An anthropometry profile and lipid profile at pre and post-study is presented in Table 2 . Anthropometry profile indicators including waist circumference, WHCR; and lipid profile represented by systolic blood pressure, cholesterol, LDL, HDL, and triglycerides had significant differences for both groups before and after the study. Only body fat percentage had significant difference at pre-post study between the groups.

Table 3 showed mean macro and micro-nutritional intake before and after the intervention. Each group had significant difference in fat, carbohydrate, and vitamin $\mathrm{E}$ intakes from before to after the study. Both groups had significance differences in protein intake at pre-post study with intervention group was a little bit higher than control group. Table 4 showed the macro-micronutrients contained 
in both types of biscuit. The caromma biscuit had lower energy, fat, Fe, $\mathrm{Zn}$ than the temma biscuit. The fiber content in caromma biscuit was slightly higher, but the cholesterol content was slightly higher compared to the temma biscuit.

\section{Discussion}

Most subjects in both groups were overweight and obese due to their high body fat level, especially in the abdomen, leading to insulin effect resistance. This was supported by the majority of subjects having a WHCR higher than the cut off points mean defining obesity (WHO, 2008). Commonly, type $2 \mathrm{DM}$ patients experienced dyslipidemia in the form of lipid metabolism disorder, i.e., increased total cholesterol level, triglycerides, LDL, and decreased HDL (Gordon et al, 2010). Decreased FBG level, cholesterol, LDL, and triglycerides in the intervention group of this study was consistent with a study of type 2 diabetes patients in India (Agrawal et al, 2012). However, no significant changes were found in the anthropometry profile of BMI and WHCR. Glycemic control was positively correlated with the blood triglyceride level. Excess glucose in the blood is stored in the form of fat, especially triglycerides during the advanced phase of the pathogenesis process of type 2 DM. Glucose was transformed into triglycerides, leading to an increased triglycerides level, which causes a lower HDL level and an increased cholesterol level in the blood (Parhofer KG, 2015).

Caromma biscuit can decrease FBG of diabetes patients by the high fiber content in mocaf flour (Tempo, 2014). This was in accordance with a pilot study, which found an increase of blood glucose post-prandial two hours after consuming the caromma biscuit in type 2 diabetics with the lowest point of 6.4 amongst the other kind of biscuits (Fatmah, 2017). The caromma biscuit had low GI value (< 55) according to the American Diabetes Association (ADA, 2014; Healthy Magazine, 2011; Food \& Nutrition Center Laboratory of Gajah Mada University, 2015). It can decrease cholesterol absorption, dilute toxins, and increase short-chain fatty acid production. The high fiber content in mocaf flour as the main ingredient of caromma biscuit is assumed to help decrease cholesterol (Sinta, 2013). This was in line with the study conducted on type 2 DM patients. Cholesterol and LDL significantly decreased in type 2 DM patients after applying a low glycemic index diet (Majchrzak LC et al, 2014; Jarvi AE et al., 1999; Wolever TM et al, 1992; Fahime Z et al, 2016). Date jam has been proven not to increase the blood glucose level of diabetics because it contains low GI (Munadi and Dedi A, 2002).

Caromma and temma biscuits had low glycemic index. A low glycemic index diet in type 2 diabetic patients can decrease weight, BMI, and hip circumference (Lopez SV and Sandra NMK, 2009; Duygu S et al, 2018; Fatemeh $S$ et al, 2019). Dates contained several phytochemicals such as carotenoid, polyphenol (phenolic acid), isoflavone, lignin, flavonoid, tannin, and sterol and fiber that can inhibit the absorption of LDL cholesterol. A study on date diet in rats with $1.5 \%, 2.5 \%$, and $5.2 \%$ content can decrease triglycerides, cholesterol. Another study conducted on a healthy population with dates consumption found no increase of FBG, with triglycerides decreased by 15\% (Mohan J, no year). Limited subject size and duration of intervention may not prove a significant correlation between the effect of caromma biscuit consumption and changes in anthropometry profile such as BMI and WHCR. Further studies are needed to prove both of the above with a larger number of subjects and a different intervention duration. In conclusion, the consumption of caromma and temma biscuits has potency affecting blood lipid profile positively (decrease cholesterol, LDL, and triglycerides). 


\section{Acknowledgement}

We would like to acknowledge DP2M Kemenristekdikti who funded this program through Hibah Penelitian PUPT Lanjutan 2016 and all subjects that participated until the end of this study.

\section{References}

Agrawal et al. (2010). "Effect of oyster mushroom on glycemia, lipid profile and quality of life in type 2 diabetic patients". Australian Journal of Medical Herbalism, Vol 22 No 2, pp. 50-54.

American Diabetes Association. (2011). "Standards of medical care in diabetes-2011". Diabetes Care 2011, Vol 34 (Supplement 1), pp. S11-S61.

Chang YC, Wen-Chuan Wu. (2013). "Dyslipidemia and diabetic retinopathy". The Review of Diabetic Studies, Vol 10 No. 2-3, pp. 121-132.

Duygu S, Mendane S, Nurhan S. (2018). "The effect of consumption of low glycemic index, high fat content bread on anthropometric measurement and cardiometabolic risk factors in women with type 2 diabetes mellitus". International Journal of Diabetes in Developing Countries, Vol 39 No 1, pp. 166-172.

Fahime Z, Hadis AS, Omid T, Shima A et al. (2016). "A review of the relationship between dietary glycemic index and glycemic load and type 2 diabetes". Journal of Nutrition and Food Security, Vol 1 No. 1, pp.: 73-79.

Fatemeh S, Saedeh S., Ali K, Masoumeh A. (2019). "Effect of natural honey on glycemic control and anthropometric measures of patients with type 2 diabetes: a randomized controlled crossover trial". Int $\mathrm{J}$ Prev Med, Vol 10, No. 3, pp: no page.

Fatmah. (2017). "Effect of modified cassava flour lentil date biscuit on the blood glucose level of diabetics". Pakistan Journal of Nutrition, Vol 16 No. 1, pp.16-21.

Food and Nutrition Laboratory of Gajah Mada University. (32015). Glychemic index of Temma, Caromma, and Bisma Biscuits. Yogyakarta.

Gordon L., Dalip R., Errol YAM, Eric CK, et al. (2010). Lipid Profile of Type 2 Diabetic and hypertensive patients in the Jamaican Population, Vol 2, No.1, pp. 25-30.

Healthy Magazine. (2011). Indeks glikemik: arti dan manfaatnya. http://www.majalahkesehatan.com/indeks-glikemik-arti-dan-manfaatnya. Diakses tanggal 5 Januari 2014.

Hirano T. (2018). "Pathophysiology of diabetic dyslipidemia". J Atheroscler Thromb, Vol 25, pp. 771-782.

Jain HR, Shetty V, Singh GS, Shetty S. (2016). "A study of lipid profile in diabetes mellitus". International Journal of Scientific Study, Vol 4 No 9, pp.56-61.

Jain SM. (2015). "Health benefits of date palm: phytochemicals and their functions", paper presented at 3rd International Conference and Exhibition on Pharmacognosy, Phytochemistry \& Natural Products, October 26-28 2015, India, available at https://www.longdom.org/proceedings/health-benefits-of-datepalm-phytochemicals-and-their-functions-30053.html

Jarvi AE, Karlstrom BE, Granfeldt YE, Bjorck IE et al. (1999). "Improved glycemic control and lipid profile and normalized fibrinolytic activity on a low-glycemic index diet in type 2 diabetic patients". Diabetes Care, Vol 22 No. 1, pp. 8-10.

Kelley DE. (2003). "Sugars and starch in the nutritional management of diabetes mellitus". Am J Clin Nutr, Vol 78 No 4, pp. 858S-864S.

Lopez SV, Sandra NMK. "Use of the glycemic index for weight loss and glycemic control: a review of recent evidence". Current Diabetes Report, Vol 9 No 5, pp. 379-399.

Ministry of Health. (2018). Basic Health Research 2018. MOH, Jakarta.

Centre of University Gajah Mada Laboratory. (2015). Analyst test of modified cassava flour lentil dates biscuit. Gajah Mada University, Yogyakarta.

Parhofer KG. (2015). "Interaction between glucose and lipid metabolism: more than diabetic dyslipidemia”. Diabetes Metb J, Vol 39, pp. 353-362. 
Majchrzak LC, Teresa G, Marta K, Krystyna C et al. (2014). "The use of low-carbohydrate diet in type 2 diabetes- benefits and risks". Annals of Agricultural and Environmental Medicine, Vol 21 No 2, pp. 320236.

Munadi and Dedi A. (2008). "Blood glucose change of controlled type 2 diabetic at post dates consumption". Nusantara Medical Magazine, Vol 41 No 1, pp. 29-35.

Samuel- Jack. (2006). "Primary prevention of type-2 diabetes in developing countries". Journal of the National Medical Association, Vol 98 No 3, pp.415-419.

Sastroasmoro S., Sofyan I. (2014). Dasar-Dasar Metodologi Penelitian Klinis 5th edition. Sagung Seto, Jakarta.

Sinta. (2013). Modified cassava flour as wheat flour replacer, available at: http://www. http://shintaluki.blogspot.com/2013/11/mocaf-sebagai-pengganti-terigu.html, accessed 10 January 2014.

Tempo. (2014). "Obat diabetes dari tepung kacang koro pedang", available at http://www.tempo.co/read/news/2011/12/08/095370608/Obat-Diabetes-dari-Tepung-Kacang-Koro, accessed 5 January 2014.

Wolever TM, Jenkins DJ, Vuksan V, Jenkins AL et al. (1992). "Beneficial effect of low-glycemic index diet in overweight NIDDM subjects". Diabetes Care, Vol 15 No 4, pp. 562-4.

WHO. (2008). Waist-circumference and waist-hip ratio: report of a WHO expert consultation, Geneva, 811 December 2008. www.who.int. 


\section{Appendix}

Table 1 Socio-demography characteristic of the subjects

\begin{tabular}{|c|c|c|c|c|}
\hline \multirow[t]{3}{*}{ Variable } & \multicolumn{4}{|c|}{ Type of biscuit } \\
\hline & \multicolumn{2}{|c|}{ Group 1:caromma $(\mathrm{n}=33)$} & \multicolumn{2}{|c|}{ Group 2: emma $(n=31)$} \\
\hline & $\mathrm{n}$ & $\%$ & $\mathrm{n}$ & $\%$ \\
\hline \multicolumn{5}{|l|}{ Sex: } \\
\hline Male & 6 & 18.2 & 3 & 9 \\
\hline Female & 27 & 81.8 & 28 & 90.3 \\
\hline \multicolumn{5}{|l|}{ Age : } \\
\hline$<60$ y.o & 19 & 57.6 & 20 & 64.5 \\
\hline$>=60$ y.o. & 14 & 42.4 & & 35.5 \\
\hline Mean + SD & & +9.9 & & 8.7 \\
\hline \multicolumn{5}{|l|}{ Last education level: } \\
\hline $\begin{array}{l}\text { Low (did not graduate from } \\
\text { elementary - junior high school }\end{array}$ & 20 & 60.6 & 21 & 67.7 \\
\hline $\begin{array}{l}\text { Middle (graduated from senior } \\
\text { high school - academy/universi }\end{array}$ & $\begin{array}{l}13 \\
\text { ity) }\end{array}$ & 39.4 & 10 & 32.3 \\
\hline \multicolumn{5}{|l|}{ Working status now: } \\
\hline Does not work & 26 & 78.8 & 27 & 87.1 \\
\hline Works & 7 & 21.2 & 4 & 22.9 \\
\hline
\end{tabular}

Table 2. Anthropometry and lipid profiles of subjects at pre-post study

\begin{tabular}{|c|c|c|c|c|c|c|c|c|}
\hline & $C_{0}$ & Pre & & & Po & & & * \\
\hline & Uroup & $\mathrm{n}$ & Mean & $\mathrm{SD}$ & $\mathrm{N}$ & Mean & SD & \\
\hline Weight & Caromma & 33 & 58.60 & 12.67 & 33 & 58.84 & 12.55 & 0.002 \\
\hline & Temma & 31 & 61.18 & 9.33 & 31 & 61.37 & 9.60 & 0.057 \\
\hline & $\mathrm{P}$ & & 0.359 & & & 0.371 & & \\
\hline BMI & Caromma & 33 & 24.47 & 5.62 & 33 & 24.56 & 5.55 & 0.008 \\
\hline & Temma & 31 & 26.68 & 3.82 & 31 & 26.75 & 3.92 & 0.072 \\
\hline & $\mathrm{P}$ & & 0.073 & & & 0.075 & & \\
\hline Body fat percentage & Caromma & 33 & 32.18 & 6.83 & 33 & 32.68 & 7.22 & 0.400 \\
\hline & Temma & 31 & 35.96 & 5.34 & 31 & 35.90 & 5.15 & 0.907 \\
\hline & $\mathrm{P}$ & & 0.017 & & & 0.046 & & \\
\hline Waist circumference & Caromma & 33 & 80.16 & 13.73 & 33 & 83.09 & 13.43 & 0.000 \\
\hline & Temma & 31 & 84.04 & 9.52 & 31 & 87.51 & 8.51 & 0.000 \\
\hline & $\mathrm{P}$ & & 0.197 & & & 0.123 & & \\
\hline Hip circumference & Caromma & 33 & 93.92 & 11.68 & 33 & 95.36 & 11.96 & 0.046 \\
\hline & Temma & 31 & 97.63 & 9.84 & 31 & 98.31 & 7.88 & 0.504 \\
\hline & $\mathrm{P}$ & & 0.176 & & & 0.253 & & \\
\hline
\end{tabular}




\begin{tabular}{|c|c|c|c|c|c|c|c|c|}
\hline \multirow[t]{3}{*}{ Waist/hip circumference } & Caromma & 33 & 0.85 & 0.67 & 33 & 0.86 & 0.65 & 0.015 \\
\hline & Temma & 31 & 0.86 & 0.66 & 31 & 0.88 & 0.40 & 0.006 \\
\hline & $\mathrm{P}$ & & 0.494 & & & 0.147 & & \\
\hline \multirow[t]{3}{*}{ Sistolic blood pressure } & Caromma & 33 & 121.52 & 16.23 & 33 & 115.76 & 18.71 & 0.029 \\
\hline & Temma & 31 & 128.39 & 16.55 & 31 & 117.42 & 19.66 & 0.001 \\
\hline & $\mathrm{P}$ & & 0.099 & & & 0.730 & & \\
\hline \multirow[t]{3}{*}{ Diastolic blood pressure } & Caromma & 33 & 87.88 & 9.60 & 33 & 85.76 & 7.92 & 0.182 \\
\hline & Temma & 31 & 88.71 & 9.91 & 31 & 87.10 & 7.83 & 0.378 \\
\hline & $\mathrm{P}$ & & 0.735 & & & 0.499 & & \\
\hline \multirow[t]{3}{*}{ Fasting blood glucose } & Caromma & 33 & 167.06 & 82.80 & 33 & 154.85 & 95.10 & 0.150 \\
\hline & Temma & 31 & 173.19 & 92.72 & 31 & 150.06 & 73.64 & 0.095 \\
\hline & $\mathrm{P}$ & & 0.781 & & & 0.824 & & \\
\hline \multirow[t]{3}{*}{ Cholesterol } & Caromma & 33 & 239.73 & 35.30 & 33 & 195.70 & 34.13 & 0.000 \\
\hline & Temma & 31 & 264.42 & 75.10 & 31 & 204.68 & 37.11 & 0.000 \\
\hline & $\mathrm{P}$ & & 0.072 & & & 0.317 & & \\
\hline \multirow[t]{3}{*}{ LDL } & Caromma & 33 & 145.18 & 29.89 & 33 & 122.24 & 29.00 & 0.000 \\
\hline & Temma & 31 & 154.97 & 53.59 & 31 & 125.45 & 30.56 & 0.001 \\
\hline & $\mathrm{P}$ & & 0.114 & & & 0.668 & & \\
\hline \multirow[t]{3}{*}{ HDL } & Caromma & 33 & 61.00 & 17.76 & 33 & 51.12 & 15.40 & 0.000 \\
\hline & Temma & 31 & 59.68 & 13.28 & 31 & 49.48 & 11.52 & 0.000 \\
\hline & $\mathrm{p}$ & & 0.738 & & & 0.633 & & \\
\hline \multirow[t]{3}{*}{ Trigliserida(sp) } & Caromma & 33 & 175.09 & 112.64 & 33 & 123.67 & 73.69 & 0.000 \\
\hline & Temma & 31 & 226.00 & 172.56 & 31 & 152.48 & 99.88 & 0.007 \\
\hline & $\mathrm{p}$ & & 0.423 & & & 0.192 & & \\
\hline
\end{tabular}

p: uji t independen, $\mathrm{p}^{*}$ uji t dependent

Table 3 Macro-micronutrient intakes changes of subjects at pre-post study

\begin{tabular}{|c|c|c|c|c|c|c|c|c|}
\hline \multirow{2}{*}{ Type of nutrient } & \multirow{2}{*}{ Group } & \multicolumn{2}{|c|}{ Pre-study } & \multicolumn{4}{|c|}{ Post-study } & \multirow{2}{*}{$\mathrm{p}^{*}$} \\
\hline & & $\mathrm{n}$ & Mean & DS & $\mathrm{n}$ & Mean & DS & \\
\hline \multirow[t]{3}{*}{ Energy (kkal) } & Caromma & 33 & 1124.82 & 422.22 & 33 & 1237.85 & 358.28 & 0.161 \\
\hline & Temma & 31 & 988.86 & 266.12 & 31 & 1107.77 & 234.87 & 0.038 \\
\hline & $\mathrm{p}$ & & 0.131 & & & 0.093 & & \\
\hline \multirow[t]{3}{*}{ Protein (gr) } & Caromma & 33 & 38.13 & 18.38 & 33 & 42.81 & 8.95 & 0.130 \\
\hline & Temma & 31 & 35.28 & 15,14 & 31 & 38.10 & 8.04 & 0.320 \\
\hline & $\mathrm{p}$ & & 0.502 & & & 0.031 & & \\
\hline \multirow[t]{3}{*}{ Fat (gr) } & Caromma & 33 & 34.81 & 19.93 & 33 & 46.25 & 11.37 & 0.001 \\
\hline & Temma & 31 & 34.87 & 15.33 & 31 & 46.06 & 11.91 & 0.001 \\
\hline & $\mathrm{p}$ & & 0.990 & & & 0.948 & & \\
\hline Carbohydrate (gr) & Caromma & 33 & 154.24 & 69.05 & 33 & 190.51 & 41.07 & 0.003 \\
\hline
\end{tabular}


Proceeding of the Public Health and Well-being Conference, Vol. 1, 2019, pp. 35-43

\begin{tabular}{|c|c|c|c|c|c|c|c|c|}
\hline & Temma & 31 & 129.54 & 59.84 & 31 & 172.75 & 33.29 & 0.001 \\
\hline & $\mathrm{p}$ & & 0.132 & & & 0.063 & & \\
\hline \multirow[t]{3}{*}{ Fiber (gr) } & Caromma & 33 & 6.31 & 3.22 & 33 & 8.14 & 3.05 & 0.004 \\
\hline & Temma & 31 & 6.61 & 3.53 & 31 & 7.99 & 2.57 & 0.060 \\
\hline & $\mathrm{p}$ & & 0.720 & & & 0.833 & & \\
\hline \multirow[t]{3}{*}{ Cholesterol (gr) } & Caromma & 33 & 156.94 & 156.36 & 33 & 143.30 & 66.89 & 0.604 \\
\hline & Temma & 31 & 81.73 & 86.20 & 31 & 128.20 & 72.24 & 0.015 \\
\hline & $\mathrm{p}$ & & 0.021 & & & 0.389 & & \\
\hline \multirow[t]{3}{*}{ Vitamin A $(\mu \mathrm{g})$} & Caromma & 33 & 343.72 & 456.29 & 33 & 455.83 & 295.10 & 0.269 \\
\hline & Temma & 31 & 227.85 & 220.88 & 31 & 454.24 & 313.85 & 0.000 \\
\hline & $\mathrm{p}$ & & 0.205 & & & 0.983 & & \\
\hline \multirow[t]{3}{*}{ Vitamin E (mg) } & Caromma & 33 & 1.44 & 3.37 & 33 & 0.11 & 0.16 & 0.026 \\
\hline & Temma & 31 & 1.23 & 2.50 & 31 & 0.15 & 0.19 & 0.018 \\
\hline & $\mathrm{p}$ & & 0.778 & & & 0.425 & & \\
\hline \multirow[t]{3}{*}{ Vitamin C (mg) } & Caromma & 33 & 38.37 & 57.58 & 33 & 38.36 & 30.43 & 0.821 \\
\hline & Temma & 31 & 32.63 & 32.29 & 31 & 41.83 & 33.43 & 0.220 \\
\hline & $\mathrm{p}$ & & 0.628 & & & 0.666 & & \\
\hline \multirow[t]{3}{*}{ Natrium (mg) } & Caromma & 33 & 457.00 & 614.56 & 33 & 474.61 & 214.91 & 0.781 \\
\hline & Temma & 31 & 587.78 & 719.53 & 31 & 415.34 & 224.57 & 0.217 \\
\hline & $\mathrm{p}$ & & 0.436 & & & 0.285 & & \\
\hline \multirow[t]{3}{*}{ Calcium (mg) } & Caromma & 33 & 214.85 & 228.46 & 33 & 237.48 & 244.48 & 0.400 \\
\hline & Temma & 31 & 232.04 & 227.80 & 31 & 197.07 & 150.55 & 0.208 \\
\hline & $\mathrm{p}$ & & 0.764 & & & 0.432 & & \\
\hline \multirow[t]{3}{*}{ Iron (mg) } & Caromma & 33 & 5.25 & 3.58 & 33 & 7.72 & 4.14 & 0.000 \\
\hline & Temma & 31 & 8.26 & 7.25 & 31 & 7.55 & 4.60 & 0.613 \\
\hline & $\mathrm{p}$ & & 0.038 & & & 0.876 & & \\
\hline \multirow[t]{3}{*}{ Zinc (mg) } & Caromma & 33 & 4.25 & 2.49 & 33 & 4.38 & 0.97 & 0.024 \\
\hline & Temma & 31 & 4.82 & 2.71 & 31 & 4.78 & 0.95 & 0.931 \\
\hline & $\mathrm{p}$ & & 0.379 & & & 0.104 & & \\
\hline
\end{tabular}

p:independent t-test, $\mathrm{p}^{*}$ : dependent t-test

DS : Deviation standard

Table 4 Nutrient contents of 100 gram biscuit

Type of biscuit Energy Carbohydrate Protein Fat Natrium Iron Zinc Vit. A Fiber Cholesterol

\begin{tabular}{lcccccccccc} 
& $(\mathrm{kkal})$ & $(\mathrm{gr})$ & $(\mathrm{gr})$ & $(\mathrm{gr})$ & $(\mathrm{mg})$ & $(\mathrm{mg})$ & $(\mathrm{mg})$ & (IU) & (gr) & $(\mathrm{mg})$ \\
\hline Caromma & 486 & 67.6 & 9.62 & 21,9 & 455 & 1.4 & 0.96 & 168 & 3.23 & 79.1 \\
Temma & 490 & 61.8 & 9.62 & 22,7 & 267 & 1.9 & 1.9 & 139 & 2.93 & 62.4 \\
\hline
\end{tabular}

Source: BBIA Laboratory 2016 